Meta

Journal des traducteurs

Translators' Journal

\title{
The Opaque Medium
}

\section{John Glassco}

Volume 14, numéro 1, mars 1969

URI : https://id.erudit.org/iderudit/002924ar

DOI : https://doi.org/10.7202/002924ar

Aller au sommaire du numéro

Éditeur(s)

Les Presses de l'Université de Montréal

ISSN

0026-0452 (imprimé)

1492-1421 (numérique)

Découvrir la revue

Citer cet article

Glassco, J. (1969). The Opaque Medium. Meta, 14(1), 27-30.

https://doi.org/10.7202/002924ar

Ce document est protégé par la loi sur le droit d'auteur. L'utilisation des services d'Érudit (y compris la reproduction) est assujettie à sa politique d'utilisation que vous pouvez consulter en ligne.

https://apropos.erudit.org/fr/usagers/politique-dutilisation/
Cet article est diffusé et préservé par Érudit.

Érudit est un consortium interuniversitaire sans but lucratif composé de l’Université de Montréal, l'Université Laval et l'Université du Québec à Montréal. Il a pour mission la promotion et la valorisation de la recherche. https://www.erudit.org/fr/ 


\section{the opaque medium

\section{REMARKS ON THE TRANSLATION OF POETRY WITH A SPECIAL REFERENCE TO FRENCH.CANADIAN VERSE}

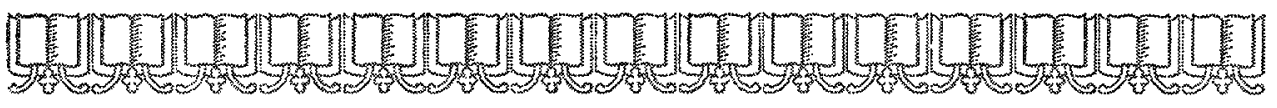

The translation of poetry is often decried. It has become fashionable to repeat Robert Frost's remark that what gets lost in the process is \& the poetry itself $»$ - or, as Sir John Denham put it rather less succinctly three hundred years earlier, "the subtile Spirit of poesie evaporates entirely in the transfusion from one language to another $»$, though he added the saving qualification, « unless a new, or an original spirit is infused by the Translator himself $\gg$. This infusion remains the mark of good translation; and difficult as it is, the operation must always be ruled by the architecture of the poem itself, which is necessarily laid bare. Faithful translation especially, which can seldom hope - and in the opinion of some should never try - to reproduce the music or magic of the original, is in fact the strictest examination which a poem's intimate structure can undergo, an ultimate screening which may leave it nothing but its intellectual content or \& meaning », its images and inner pulsation; for Mallarmé's clever riposte to Degas is only half true: poetry is made out of words, but poems themselves - as Mallarmé must have known - do not begin with words but with ideas, moods, concepts, formulations of emotion. The scales of translation are thus weighted in favour of a poetry marked by clarity of thought and expression, spare and striking imagery, and a simple internal movement: the work of Virgil, Dante, Villon and Baudelaire - to take four examples at random - lends itself admirably to versions in other tongues; while that of Catullus, Tasso, Hugo and Verlaine does not; Rimbaud's richly allusive prose-poems are almost unreadable in translation, though his sonnets and «ballads », due to their comparative simplicity, come through quite well.

But it is not only the ideas and progression of a poem which are exposed by translation: the temper and complexion of the poet himself are so mercilessly revealed as to justify the wry old equation of traduttore, traditore. This betrayal, which is part of the translator's enforced role of analytical critic, is inevitable. For the good translator is obliged, whether he like it or not, either to take the line laid down by Lord Roscommon in that ingenuous couplet, 
Your author always will the best advise;

Fall when he falls, and when he rises rise,

or yield to the temptation to beautify and «improve», and thus perhaps carry the process of betrayal still further.

Why then, it may be asked, make translations of poetry at all ? If the result is a loss, a depreciation, a betrayal, surely the expense of effort, the dizzying labour of trying to transmute the essence of that most incommensurable thing, a poem, might be better applied elsewhere - even in following Ezra Pound's advice to «make it new », that is, to misread the text in a fit of inspired illiteracy and make another poem altogether. But is not this question only another and insidious way of asking why poetry itself should be written? The poet, as Saint-Denys-Garneau found, is aware sooner or later that in pursuing his vocation he is exposing, depreciating and betraying himself, and finally failing to express the reality of his experience; but this does not stop him from writing poetry. In the same way, the devoted translator of poetry will not be balked: he is possessed by the necessity of making a translation - in the older, religious sense of a conveyance or assumption, as of Enoch or Elijah - of the vision of reality he has received from a poem, and of communicating his experience to those of another tongue; and when he wholly succeeds, as he sometimes does, the sense of achievement is that of poetic creation itself. At the worst, he has made a bridge of sorts.

The history of serious translation of French-Canadian poetry is short, covering little more than a dozen years and comprising only the collections of Jean Beaupré and Gael Turnbull (1955), G.R: Roy (1958), P.F. Widdows (1960), F.R. Scott (1964) and Peter Miller (1964), although isolated groups of poems have appeared from time to time in books, newspapers and the little magazines; and almost all the chosen poets date from within the last twenty-five years. Of translations done before 1950 there is little worth preserving except for antiquarian reasons - some of the happy exceptions being the work in the thirties of Regina Shoolman, A.M. Klein, W.R. Eadie and Grace Davignon. Going further back, one has only to read the translations done around the turn of the century, with their faded prettiness, poetic diction and Victorian tinkle, to appreciate the new, profound and sensitive treatment accorded the poetry of French Canada within the last five years.

The leading figure in this field so recently opened up is undoubtedly F.R. Scott, whose early renderings of Garneau, Hébert, Hénault, Trottier, Pilon and Giguère are still outstanding, his taste, fidelity and grasp of the movement of each poem are always admirable, and his versions could serve as models: he is Canada's first artistic translator of poetry - and his recent versions of young poets like Fernand Ouellette and Jacques Brault show that his hand has lost none of its cunning. The joint work of Beaupré and Turnbull - whose little mimeographed pamphlets, produced in Iroquois Falls in 1955-1956, are now collectors' items - has in spite of all its faults a place of honour as the first example of collective poetry translation in this country; Roy's miscellany is noteworthy as an example of poetry translation at its weakest; while Widdows and Miller, in their selections from the work of Nelligan and Grandbois respectively, 
have given English readers a glimpse, at least, of two important poets of French Canada. In the last two years, however, the translation of French-Canadian poetry has been immeasurably enriched by the work of such outstanding English-Canadian poets as G.V. Downes, Louis Dudek, R.A.D. Ford, Eldon Grier, Ralph Gustafson, George Johnston, Jay Macpherson, James Reaney, A.J.M. Smith and Francis Sparshott ${ }^{1}$.

This recent access of fine new work may be taken as a hopeful sign for the future. On the other hand, the growing enthusiasm for translating FrenchCanadian poetry has brought certain problems in its train.

The translation of poetry is one of the most difficult and exacting literary disciplines. Every poet knows it is easier to write a poem than to translate one: his task is here one of veritable re-creation, and is moreover made harder and more discouraging by the virtual impossibility - except in very rare cases - of at once doing justice to the original and remaining faithful to it, and by the constant necessity of choosing between the two challenges of fidelity and true poetry. The translator must therefore not only thoroughly understand the language of his original text, as well as be familiar with the whole body of its literature, but he must also be a good poet himself. If only one of these conditions is met, the result will be an exercise in either graceless pedantry or laughable misunderstanding, and where both are lacking we will have, alas, such absurdities as the rendering of this line of Grandbois,

Une extraordinaire ivresse coulait le long de mes frissons et mes pas

imaginaient la mesure d'une immobilité fatalement dérisoire ${ }^{2}$

as

An extraordinary intoxication ran the length of my shivers and my steps

imagined the measure of a fatally derisive immobility;

or these lines of André Major

je parle d'une terre froide à nourrir de brûlures

je parle pour qui passe innocent dans la machine à épuisement ${ }^{3}$

as

I speak about a cold country in which to nourrish burns

I speak for one who passed them by without knowing in his worn-out tricks; or these of Gaston Miron,

Et je m'écris sous la loi d'émeute

je veux saigner sur vous pour toute l'affection ${ }^{4}$

as

And of me I write in riot's grip

wanting by every affected place to bleed on you;

or even these of Anne Hébert,

1. A comprehensive collection of the best of all this work, presenting French-Canadian poetry from Crémazie to the present day and comprising more than 200 poems, has been edited by the present writer and will appear in the spring under the imprint of Oxford University Press (Toronto).

2. From Ah, toutes ces rues..., in les Iles de la nuit, 1944.

3. From Verte ma parole, in le Pays, 1963.

4. From l'Homme agonique, uncollected. 
L'allée de pins

Se ravine

Comme un mauvais chemin 5

as

The alley of pines

Yawns open

Like a bad road;

all of which, and countless others equally ridiculous, have appeared in reputable anglophone literary magazines within the last two years, and several in publicly subsidized books.

It is regrettable that such displays of ignorance and laziness are multiplying faster than good translations - though it is only natural they should, since they demand so little time or effort. But it is also dangerous; for there is a law, corresponding to Gresham's, by which bad translation smothers and drives out good, the translatee becoming in a sense the property of his first translator, for beiter or worse, and bad translations acquiring a kind of squatters' rights in the eyes of both reader and publisher.

The remedy is of course in the poet's own hands: he can refuse to allow a bad translation to be printed. But he is often unable to judge; and in almost all cases the temptation of seeing his work in another language will outweigh all other considerations. The situation is further confused by the fact that many trans'ations of French-Canadian poems are now being printed without their authors' permission or even knowledge.

It may be argued that these are, after all, only small clouds in the sky, that any interest in the riches of French-Canadian poetry, now enjoying the most important revolution and renascence in its history, must be welcomed, and that even the worst translation cannot wholly spoil its original, since something of the emotion, the images, the pulse and internal movement, always comes through, as in a palimpsest. But this is really fair neither to the public nor the original poet. The poetry of French Canada should not be presented to its wide and growing anglophone audience in the form of travesty: if it continues to be so, thus evoking merely puzzlement, disdain or laughter - and goodness knows the above examples can evoke nothing else - no good will have been served. The peculiar genius, delicacy and insight of French-Canadian poetry will have been hopelessly stultified and misrepresented, and the wretched traduttore-traditore equation confirmed. The only remedy rests with the subsidizing bodies, which must be persuaded that the translation of poetry calls for linguistic competence, taste and poetic ability, and that nothing less than this will do.

JOHN GLASSCO

5. From Vieille image, in le Tombeau des rois, 1953. 